\title{
8 Drones, Cinema, and Protest in Thailand
}

\author{
Noah Viernes
}

\begin{abstract}
The drone is defined within the duality of indifference and depersonalization, but also elevates a specific technology of seeing above fluid expressions of collectivity. This chapter addresses the drone as a mechanical device and figurative analogy of clarification that helped to organize ideological divisions into an objective narrative of the 2014 military coup d'état in Thailand. To critique these droned hierarchies, I draw upon Jacques Rancière's conception of the 'politics of aesthetics' to address independent Thai cinema as a regime of 'fictionality' where the personalization of protest returns. The fictionality of Prapat Jiwarangsan and Danaya Chulphuthipong, two Thai film-makers, reconfigures the field of protest by extending its duration into an expanded realism of post-coup oppression and resistance.
\end{abstract}

Keywords: aesthetics, drone theory, cinema, Thailand, coup d'état, personalization

\section{Introduction}

Between 2006 and the 2014 coup d'états, political disagreements in Thailand were stretched across Bangkok in cinematic cuts between radical, progressive, and conservative forces competing for a place in the timeline of historical moments. The most dominant among them, the Bangkokconcentrated Yellow Shirts, built their reputation upon a street presence that ushered in the 2006 coup d'état, and drew upon this experience to promote the 2014 coup d'état that remains in place the time of writing. Represented as hostile antagonists in dominant media channels, a coalition of rural

McGarry, A., I. Erhart, H. Eslen-Ziya, O.Jenzen, U. Korkut (eds), The Aesthetics of Global Protest: Visual Culture and Communication. Amsterdam: Amsterdam University Press, 2020 DOI 10.5117/9789463724913_CHo8 
outsiders and urban dissidents known as the Red Shirts fought back to sustain a series of progressive changes that had, ironically, been achieved under the neoliberal populist prime minister, Thaksin Shinawatra. In the scopic regime of tanks, snipers, and assassinations between 2010 and 2014, the Red Shirt opposition was diffused. The opposition was further divided by post-coup re-education camps, radio station closures, the restrictions of martial law, and military-drafted constitutional articles. This chapter reflects upon visual manifestations of protest in order to move beyond existing binaries in Thailand. First, I treat dominant media tropes, especially in drone camera captures of the 2013-2014 protests, as a channelling of voices across a hierarchy of screens. Second, I demonstrate how two independent Thai films, The Asylum (2015) by Prapat Jiwarangsan and Night Watch (2015) by Danaya Chulphuthipong, recover silenced voices in their personalized disruption of media conventions.

These two short films highlight the emergence of a protest cinema because they incorporate a 'fictionality' that disrupts how bodies often appear. Positioned in a rural forest and an alienated space of the city, the characterization of seeing, hearing, and speaking extends protest beyond dominant screens. At the height of the conflict, the state mediums that captured street-based movements changed, from television and traffic cameras to technologically updated drones, but remained focused on the visual antagonisms that territorialize the event in images of disorder. This dominant protagonist-antagonist fiction worked towards a desire for consensus by foreclosing the space of politics in the vocabulary of mobs and what E.P. Thompson described as the 'spasmodic view' (Thompson 1971: 76). For the political theorist Jacques Rancière, speaking from the elevated perception of known politicians or common narrative tropes means being 'caught in a structure of the visible where everything is on show and where there is thus no longer any place for appearance' (Rancière 1999: 103). Consequently, the primacy of one regime of visibility relies on the presupposition of the evacuation of other voices from the screen. This logic of national or state representation is always a miscount of bodies that can only be recovered through what Rancière calls the 'partition of the sensible', i.e. a disruption of 'the distribution of places and roles, and the systems for legitimizing this distribution' (Rancière 1999: 28). For Thailand, dissidence did not end in the wake of the 2014 coup, but worked from a space of exile and discouragement that I address below in the possibility of an independent camera. I begin with drone cameras that captivate attention through a technological superiority analogous to the objective eye of the state. These cameras ensure that the viewer recognizes who and what matters, 
while 'independent' films fictionalize the space of protest as personalized departures where the possibility of disagreement remains.

\section{Theories of the Drone}

Between 2013 and 2014, a technologically advanced regime of images came to dominate the representation of the Thai polis in Bangkok. Unlike the horizontal redirections of modernist urban public culture like the Democracy Monument (Dovey 2001: 273), these heavily Twittered, Facebooked, and YouTubed perspectives framed the nation from new vantage points. New to the scene of protest perspectives, a bird's-eye/God's-eye view of Bangkok hovered above in the form of 'quadcopter' citizen drones buzzed through the sky to record the escalating protestor numbers and the violent clashes. Down below, official CCTV traffic cameras recorded unexpected explosions that interrupted protest movements. But the triviality of drone cameras drew out numerous perspectives around the claim to truth, objectivity and responsibility, and invited the viewer into a screen that captured all sides. The distanced gaze overlooked the affective intensity of social movements even as it framed an erratic anger towards injustice. On the screen, the People's Democratic Reform Committee (PDRC) comprised an urban mass that wore Yellow Shirts in previous editions of Bangkok protest in the past decade. They sought the end of the so-called 'Thaksin regime', an action that protestors chalked across a protest zone as if it was meant for a cinematic establishing shot. Across town, in another drone capture, the United Front for Democracy against Dictatorship (UDD), or the Red Shirts, assembled in a stadium near the nation's largest university to defend their vote. The sea of red looked more like a sporting event, like a blimp shot that eludes the unsightliness of the city. Tom Conley (2003) writes how these bird's-eye-view shots place spectators into a fantasy of 'panopticism' (2003: 216), safe from the details down below because billboards and advertisements stand out most. From drone to drone, the assembly of the people was visualized in the promotional culture of two sides heading towards confrontation. As Janjira Sombatpoonsiri remarks of the time, "[p]ublic assembly spiraled out of control, resembling a scene of civil war' (2017: 111).

It is precisely when the polis seems to be breaking apart that cameras piece it back together as total representation. On the one hand, a drone calls for security through surveillance and is replayed in the cinematic cuts between hostility to solidarity. But the distance between the camera and the spectator conceals the 'manning' of this overhead perception. The virtual immersion of the spectator at a safe remove from the scene formulates 
several questions about the mediums of protest images. First, where does the drone come from? Friedrich Kittler (1999) argued that militarization played a key role in the organization of technology, a point that can be linked to the contemporary function of a 'citizen' drone in Bangkok protests as much as the deployment of drone as a weapon in the War on Terror. 'Media determine our situation' (Kittler 1999: xxxix), he wrote, emphasizing how technology transitions from war to everyday life. In A Theory of the Drone, Grégoire Chamayou reinforces this technological collusion. The drone emerges from a dream 'to construct a bodiless force, a political body without human organs' (2015: 221). He is referring to a transition from a collective sovereignty that internalizes an image of the people to a mechanical apparatus that hovers above them. But what happens when citizens deploy technology against the state? On 11 June 2013, some months before the Bangkok protests began, Turkish police shot down a citizen drone as it framed the tear-gassing of Taksim Square. In Forbes magazine, Michael Peck (2013) described the incident as a global confrontation between state abuse and citizen-made visual cultures attempting to increase transparency. It is hard to know when exactly the transition to this 'objective' drone began and, specifically, when the politics of protest was narrowed to two sides captured in this vertical reality. In November 2011, a 'talented handyman' sent a RoboKopter drone into the airspace of a Polish Independence Day parade to capture the escalating confrontations between the extreme right-wing nationalists and antifascist protestors (Lambert 2013: 61). From the Euromaidan protests to the far-right violence in Charlottesville, Virginia, in 2018, the remote eye of the drone hovers in the sky as an objective party establishing the boundaries of division and debate.

In the Thai case, protest drones responded to a practical concern among videographers entering a precarious field of violence. In his journal entries about the 2010 Red Shirt protests, Claudio Sopranzetti (2012) observed that a large gathering of videographers is a sign of danger driven by a need to capture hostility. Because the polarity of division is never resolved, visual evidence is preferred. Could it be that perceptions of the body politic would change, if we consider how this public evidence converses with other personalized cameras? How might we think protest as an assemblage of projections, images, and frames assembled more around aesthetic dimensions than state tropes? My response is rooted in the post-coup strategies of dissidence in Thailand, especially those confronted by the polarizing distance of politics under dictatorship. Better-known protest strategies confront dictatorship publically, either through mass movements such as the Yellow Shirts or the Red Shirts, or, more recently, through decentralized anti-coup groups, such 


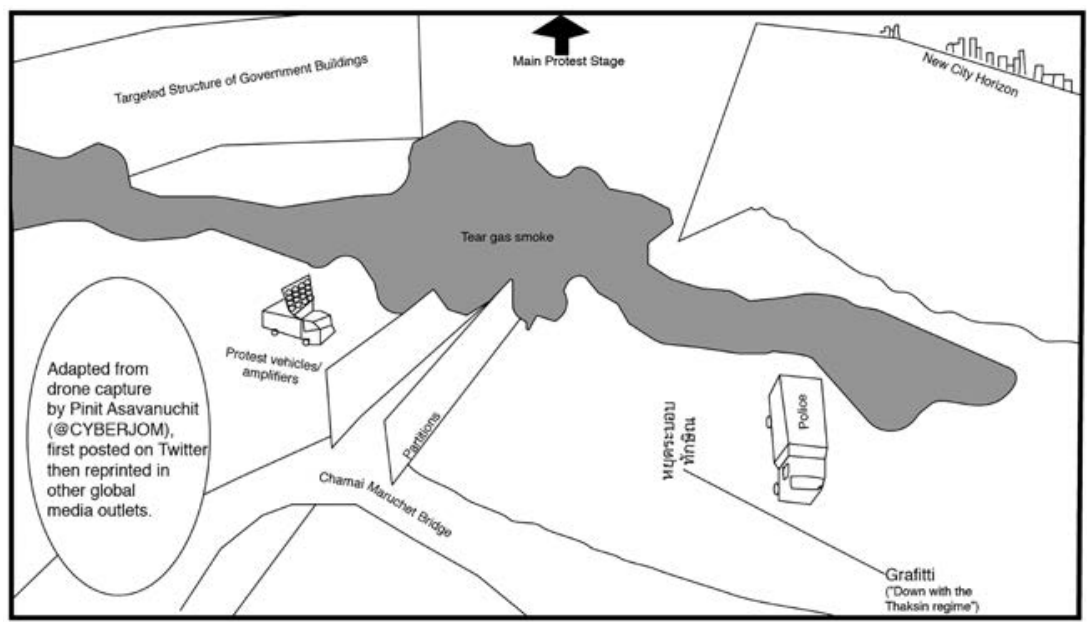

Figure 8.1. Drone Space. Self-sketch of a drone capture.

as Resistant Citizen, whose tactics range from public assembly on mass transit lines to music videos. The latter groups not only inspire an extended duration of protest beyond the official timeline of national events, but also trigger me to search for other manifestations of protest in Thailand today. As dictatorship persists, the space of departure from the public realm expands. In these departures, protest becomes a parallel space for complicating the prominence of true images with an affective imagination of resistance that takes over during the waiting period.

\section{The Militarized City}

I argue that any capture of sides is simultaneously ideological and aesthetic in that the objectivity and technological superiority of drones is undercut by the convergence of recording and seeing; as if 'overlooking' is somehow disembodied from protest. In the above image, smoke emanates from the tear gas canisters during a confrontation at Chamai Maruchet Bridge, where the Network of Student and People to Reform Thailand (NSPRT) - a security wing of the pro-military PRDC - negotiate a police cordon along the route to the nearby Government House. The PDRC escalated its disagreement with the 'populist' government in an all-out street assault as a seemingly objective drone opens new perspectives of the conflict to public view. The drone is depersonalized and alienated, removed from the street as a neutral observer of two opposing sides. This objective position renders the technology perfect for a gaze depopulated of personalities. In fact, this way 
of looking perpetuates the continuity of some rational order in what Peter Adey (2010) calls the 'aerial gaze': i.e. a view that evacuates subjectivity. 'Now, and from above, the eye is neither clouded with subjectivity nor distracted by feelings; it is calculated, it is truthful' (ibid.: 86). By conditioning the perception of protest from above, the 'gaze is filtered' into a readable plan with the potential to further the regime of control of the subjects down below. Even though the sounds of a drone, Adey emphasizes, feed the perceptual and 'affective atmospheres of fear' (ibid.: 172), the fear is displaced to off-screen zones of a coming military dictatorship. We hear these sounds in a video posted on Twitter by Pinit Asavanuchit (@CYBERJOM), but the message is silently channelled in references amplified elsewhere. 'Down with the Thaksin regime' is chalked across the pavement to mobilize our attention towards the government of his sister, Yingluck Shinawatra, as the perpetrator of disorder. Just as institutions work from the top down, so too does the God's-eye view rely on generalization. The low angles of the street might tell a different story. But why does this one prevail?

On one hand, the drone is novel and new, unlike any previous framing of Bangkok protests. The drone glides neutrally along Phitsunalok Road with a field of view that frames key actors: a police van, the government house, a security wall to protect it, the protestors attempting to breach it, and the preserved landscape of a modern bureaucratic core that reinforces dominant representations of the political alongside the skyscraper city that does not appear here. The horizon bends with the fish-eye lens that allows the drone to partially immerse in dreamy clouds of tear gas before turning towards the more populated demonstration stages. The video, entitled Chamai Clash at Dusk (Asavanuchit 2013b), is far less melodramatic than the drone operator's subsequent posts. CU against Amnesty Bill 5 Nov 2013 (Asavanuchit 2013a), for instance, engages the upbeat orchestration of an American frontier biopic and intertitles, such as 'Lecturers, staff, students and alumni rally together' in order to fold a prestigious organization into the moral order of protest. I am more interested in how it converts protest into a new form of objectivity at the expense of personality. What happens when the dominance of a technological image stands for all and no one at the same time?

The drone is the culmination of how cities coincide with 'pixels' and 'actions' since, according to Nicholas Mirzoeff (2015), political activism must become 'visual activism' if it is to communicate in contemporary terms. But often, the camera angles condition our seeing without the reminder that we were not there. On one side, a government, bolstered by the presence of riot police, seeks to hold on to power in the face of the well-organized PDRC. 
Over 150,000 people began to occupy several parts of the city at the beginning of November 2013 to intensify their grievances against the Yingluck government. The protestors were especially angered by the Amnesty Bill passed suspiciously through the House of Representatives in the early morning hours of 1 November 2013, which would have paved the return of Thaksin from exile. For Yingluck's Pheu Thai (For Thai) Party, the Amnesty Bill was originally planned as a conciliatory concession to military leaders and government officials who ordered the 2010 crackdown on the United Front for Democracy against Dictatorship (UDD) protests. But the protestors emphasized the persistence of a 'Thaksin regime' to suggest that even the military coup on 19 September 2006 could not prevent his ability to influence domestic politics. The PDRC reignited an alliance of sporadic middle-class street provocateurs and conservative, royal, and heritage-minded nationalists (Tejapira 2006; Winichakul 2008). Thai protest thus appeared as a split between these forces of the extreme right and the antagonism of a rural/ urban alliance of Thaksin-aligned neoliberal populists.

Years earlier, there were no drones to frame the Red Shirts' protest against the appointment of the urban and conservative Democrat Abhisit Vejajiva. During these 2010 protests, the emergent social media followed a similar narrative escalation by amplifying two ideological positions in dominant media outlets. The televised appearances of government security officials aligned with local radio broadcasts of a Redshirt 'mob', while hotel lobby posters played to global fears of 'rebel cities' (Harvey 2012) that must be pacified according to the prerogatives of global tourism and investment. The attempt to visualize disorder in the promotion of militarized security is precisely where disruption becomes political. Rancière writes that 'the organization of bodies as a community and the management of places, powers, and functions' (1999: 99) require constant policing of who is counted (or visualized) as part of the political body. In this distribution of sensibility, protest is the claim to visibility of 'those who have no part' in official counts, surveys and images of the political body. On Flickr, Bunika Chatakul's (2010) post of an overturned military vehicle on 11 April 2010 was neither the loudest nor exemplary of the event's main characters. Channelling a contemporary form of 'photographic amplification' (see Faulkner, this volume) we read the morning after tear gas, live fire, and the government's failure to remove Red Shirts from the city's 'heritage' district in a caption that reads 'and nothing will ever be the same'. Of course, nothing will be the same for all those who count themselves in a disrupted image of an overturned military vehicle with 'tyrant' spray-painted in red alongside numerous other graffiti tags. The photograph does not attest to a victory of the Red Shirts, but 
manifests the multiple modes of confrontation in a multimediated city. In the expanded duration of a photograph, a political subjectivity emanates; the very subjectivity that Adey (2010) finds to be evacuated from the objectivity of the drone. Inscriptions of political subjectivity are a necessary component of relocating protest from public phenomenon to the extended duration of personal experience (Al-Saleh 2015; Bordowitz 2003; Mason 2012).

Civil war in Thailand directly translates as 'war in the middle of the polis' (songkhram klang meuang), which aptly expresses why divided cities rely on a visual culture of truth and frames that appear as objective. For Bangkok, the zoomed-out drone framed the coming militarization as inevitable when it cut to street-level media. In one example from early December 2013, the PDRC-led Network of Students and People for Reform of Thailand (NSPRT) attacked buses along the route to a Red Shirt counter-protest. Passengers were forced to remove their shirts and other 'red' items. Street fights ensued, bombs were detonated, and a PDRC leader was assassinated in his motorcade. The PDRC called on the government to take responsibility for these deaths, as the army's highest-ranking general and current PM, Prayuth Chan-ocha, proposed to mediate a dialogue between the two groups. On 8 December, Yingluck dissolved the government and set elections for 2 February 2014. But in the final PDRC push, protestors returned to the streets under the name Shutdown Bangkok, Restart Thailand. As they shut down government ministries and blocked most polling stations, the 2 February election devolved into sporadic armed street battles.

Zoomed out, drones missed the perspectives of the street. Zoomed in, disorder promoted security. This multimediated sensibility climaxed in the official channels of television because this is where representation could be policed in mass media-friendly generalizations. On the evening of 22 May 2014, the end point of the PDRC protests, army general Prayuth Chan-ocha assured television audiences that Thailand would 'quickly return to a normal state' (klap su sa-pha-wa po-ka-ti doi raew). The perception and anticipation of a normal state is a sensibility that can only be reproduced through a mediated regime of policing. The police are, first, an order of bodies that defines the allocation of ways of doing, ways of being, and ways of saying, and sees that those bodies are assigned by name to a particular place and task; it is an order of the visible and the sayable that sees that a particular activity is present and another is not, that this speech is understood as discourse and another is noise (Rancière 1999: 29).

A police order ensures that the spaces and times of national protest unfold according to dominant conventions: dialogue, debate, announcements, declarations or conversation among those certified to do politics. 
But policing also means qualifying an argument through moral tropes. The PRDC broadcasts, like those of the military at the time of the 2006 coup, were framed as a minority of so-called 'good people', through the visual repetition of a centripetal centre - the well-educated capital city, loyal disciples of the king, the sacrificial protest leader (many who had resigned from their governmental positions to lead the street protests), and so on. These broadcasts were designed to organize and order the political body, so that military necessity could be justified along the pretext of security. In the absence of a clear leader, the political body becomes a legitimation mechanism for security thinking. To secure the truth is to channel some images at the expense of others. To secure an area is to lay claim to it within a sovereign field that opens during moments of institutional crisis. When convention falls apart, the military seizes power.

\section{Cinema}

The above discussions of drones, civil war, and political instability inspire two directions for this analysis of social movements. The linking of media is inevitably global. The evolution of a medium is often political. Social movements rely on the presence of cameras to mark the immediacy of time in visions of anger, disagreement, and some bipolarity in an unbalanced body (Bordowitz 2004). In 'The Pixelated Revolution', Rabih Mroué (2017) illustrates a perfect scenario of this tension in the confrontation between the low-resolution visual culture of demonstrators and the violence of the state as concealed in official Syrian media. To think through this scenario, Mroué imagines protestor film-making as an emergent global cinema that challenges prior conventions of realism in visual culture (e.g. as a critical rejoinder to the handheld film-making of the Dogme 95 manifesto that revolutionized independent film at the turn of the century). He decides to read the pixelated digital videos of the Syrian revolution to devise a manifesto capable of leading demonstrators to an 'establishment phase' where an anxious handheld aesthetic might, someday, shift towards a more fixed position. But for now, what counts is that their realism might impact our vision, and that the image-as-protest might play a larger role in how we link our eyes to cameras. Mroué cites his experience of the Lebanese Civil War when images should have counted as evidence against the amnesty of the early 199os that exonerated criminals. The pixelated images do not replace laws, but exist as a protest against the police order of the state that stabilizes their status quo in tripods, television, and moral tropes. Their shots are not meant to immortalize a moment or an event, but rather a 
small portion of their daily frustration, fragments of a diary that might one day be used in the writing of an alternative history (Mroué 2017:484).

We must, as Mroué insists, consider the challenge of each medium to its time in the recovery of what we know is happening off-screen. In the case of early 199os 'democratization' in Thailand, for instance, William Callahan (1998) wrote of the significance of post-event photographic exhibitions in crystallizing an official narrative of democratic change, while Annette Hamilton (1993) and Alan Klima (2002) wrote of the open-ended format of the blank videotape for rendering transparent the violence of the military - as crackdowns could not be aired on television. As duration, the mechanical reproduction of images inevitably brackets disagreement inside the frame of black-and-white photographs, radio waves, television, bootlegged video, social media and now drones. Mroué's point is that cinema, too, must maintain its commitment to protest as an aesthetic manifestation of collectivity. As dimly lit subjects in darkened landscapes, we might also refer to this politics in the context of what Özge Özdüzen calls 'DIY citizenship' (see Özdüzen, this volume).

With the return of the military in the 2014 coup, tension built in the space between analogue and digital technologies, for example, in the shutdown of radio stations and the seizure of data to implicate 'subversive' activity. Prapat Jiwarangsan's 2015 short film The Asylum, released one year and three months after the coup, is set in this context and links its protest to the alienating exile of military rule. In the film, a Karen immigrant boy from Myanmar and a middle-aged woman pass time together in a northern Thai jungle. For Thai cinema, the jungle exists as a multidimensional reference to exiled demonstrators of the 1970 s who fled to join a Communist insurgency. It is also a recurring space of reflection on marginality and dehumanization (for instance, in the films of Thailand's most well-known independent film-maker, Apichatpong Weerasethakul). Here, the aesthetics of protest relies on the characterization of how these characters share this space of exile as a consequence of militarization. The boy is here as a consequence of another military regime, and relegated to the condition that Giorgio Agamben calls 'bare life' by the policing of the nearby border. He passes time by throwing stones into a nearby pond. The scene recalls Agamben's work, specifically, because there is a boundary marker in the frame that aligns the forest with the Italian political theorist's reference to 'the camp' as a space where citizens are reduced to expendable bodies. While Bangkok streets appear on TV and citizen drones, the provinces do not. So too is the forest an exceptional space, i.e. 'a space in which sovereignty exists but the law does not, a territory in which actions [of the state] are neither legal nor 
illegal' (Agamben 2007: 53). Nearby, the woman recites a monologue from an imaginary Red Shirt radio station that, in real life, has been shut down in the new regime's attempt to conquer the territory north of Bangkok.

Here, the film's aesthetics of protest is the recovery of bodies that attest to the incompleteness of the Thai political image. Prapat's camera disrupts this image in what Rancière (2004: 37) cites as the space of 'fictionality' that challenges 'everything silent and the proliferation of modes of speech and levels of meaning'. This fictionality does not preclude truth, but rethinks bodies beyond the conventions of a militarized image. In treating the connection between fiction and realism, Rancière (2018: 237-238) underscores fiction's political function in the 'expansion' of 'random moments' into the lives of characters that rarely find their place in the dominant chronicles of historical moments. On 22 May 2014, the day of the twelfth successful Thai military coup, an anti-military media activist, who works under the pseudonym 'Daeng', dumped his hard drive into a river in fear that it could be used to incriminate him under the newly imposed martial law (Lee and Darin 2014). While Daeng's digital archive of regional stories are decomposing in rust, the problem is also that media stories are being forgotten and while images of the oppressed are normalized, not by our own ignorance but in their redundancy (Sontag 1973; Shapiro 2008). From Thailand's rural north-east to the Muslim south, militarization and martial law escaped the kind of coverage captured in the accumulated images of Bangkok protests. In one story, Daeng reported that a ten-year-old child was kidnapped in order to compel a dissident relative, an area radio DJ, to report to the military. The Asylum references all of these stories, in the attempt to recover bodies in images of Thai protest, but also to promote the conditions of possibility for other associations.

The Thai title of The Asylum is Dork Rak (Crown flower), which stands for a radio station closed down after the 22 May 2014 coup. While closures to rural radio stations for political reasons were not uncommon, the declaration of martial law institutionalized the repression with the exceptional conditions of national division. The ruling National Council for Peace and Order (NCPO) anticipated the end of martial law in promulgating an interim constitution on 22 July 2014, which contained the flexible Article 44 that incorporated emergency powers for the purpose of 'national security.' Defiantly onscreen, Varanee Tapanya appears in her forested exile to let the audience know that she's reporting live 'as usual', even as the boundary-marked forest and contemporaneous political context recalls the disrupted radio. It is 12 February 2015 and she has received a phone call to dedicate Pai Pongsathorn's local 'luk thung' folk song 'Wanna See You in My Dream' to three people. The song 
hints towards a dream world designed to escape the disenfranchisement of politics that aligns with a nearby bench designated as a space of waiting. So, too, are these rural audiences collectively waiting in the post-democratic imaginary. The film cuts to a young Karen boy, Ah Tay, as he throws rocks into a nearby pond. Matching the action, the camera follows the trajectory of the rocks into the pond where they sink into murky brown water. This is the space where Nietzsche located 'frog perspectives', to oppose the desire to 'paint' an objective truth that is, at best, murky (Nietzsche 2002: 6). The camera dwells in the murky water to break the narrative dependence on clarity that does not comport with their realism. The soundscape seems to accentuate the involuntary gravity of a drowning victim, or the gaze of an underwater search team. We cut back to the radio DJ's monologue as she facilitates another song dedication, and then back to a medium-shot of rocks breaking the surface of the pond. In the cut between the world above and the world below, the sound design stands out as the difference between a multiplicity of voices - from a radio DJ to the resonance of forest animals - and the indecipherability of underwater frequencies. These sounds align with multiple camera shots as parts of a 'state' in the immersive sensibility of martial law. In a move from reportage to dramaturgy, Varanee amplifies her voice through the open field of poetry in her final remark:

Courage is from within

Turn your dreams into power

So to speak, life is similar to a blanket

That is shorter than our height

To cover the shoulders,

The tip of your toes will be exposed

But to cover the toes

It will slip off from your shoulders

So what could we do to sleep soundly under this blanket?

We just have to change our sleeping posture

Try lying on the side with knees bent

You can now cover yourself up in the warm blanket all night long

Our lives are not perfect

But it's good enough

If you can adapt yourself to the imperfections of life

Troubles and dead ends ruin your dream slowly

Sadness doesn't come from others

It's your heart that carries that weight

No one gets everything they want 
Yet no one gets nothing at all

For those who lost today

Stand up straight for tomorrow

The poem expresses the off-screen temporality that partitions so-called political action from waiting, a fixed picture of protest juxtaposed with the formlessness of adaptation that prompts an aesthetic turn. Varanee is now imagined in the same kind of exile given to the Karen boy as she gathers a hand full of rocks and tosses them into the river. For progressive audiences of independent Thai film, the poem surely recalls a similar assemblage of verses read in a voice-over at the end of Apichatpong Weerasethakul's contemporaneous film Cemetery of Splendour (2015). In both cases, a narrator vocalizes the poverty of political representation where the main protagonists shine as bright as the sun. In darkness, only dreams can ensure the persistence of personal visions.

The former prime minister, Thaksin Shinawatra, in the months after the 2014 coup, advised his Red Shirt followers to 'play dead' until elections (Webb and Temphairojana 2015). But years have passed without them. Military promises of an election 'one year and three months' from the seizure of power was then pushed to 'no later than' February 2019 (Hariraksapitak 2018). Movement between the government repression of the Red Shirts in 2010 and 2014, and the prolonging of military rule, does not make narrative sense. But in the abstractions of The Asylum, a space of exile is also a space of protest where oppositional strategies are reformulated, and dominant protagonists subverted.

While the province of The Asylum projects an exiled space of waiting, Danaya Chulphuthipong's Night Watch (2015) provokes the viewer to consider the violence of continuity. The film cuts across the divergent temporalities of militarization where, through a common Bangkok neighbourhood frame, a personalized camera captures the evening landscape of 22 May 2014 coup d'état. Whereas The Asylum projects a pastoral space of exile beneath the shadowy canopy of the jungle, the nocturnal activities of Night Watch unfold from a domesticated urban view where speed and the mechanical lights of the city ensure the continuity of labour even during the interruptions of military intervention. The establishing shot is one of many windows in a vertical city where workers are surrounded by, and alienated from, other workers who evaporate in the flow of media. In prior protests, the Red Shirts were emblematic of the mobility of a working class, whereas the PDRC protest ignored these horizontal structures in vertical appeals to a hierarchy of appointed 'good people' (Radcliffe 2014). 


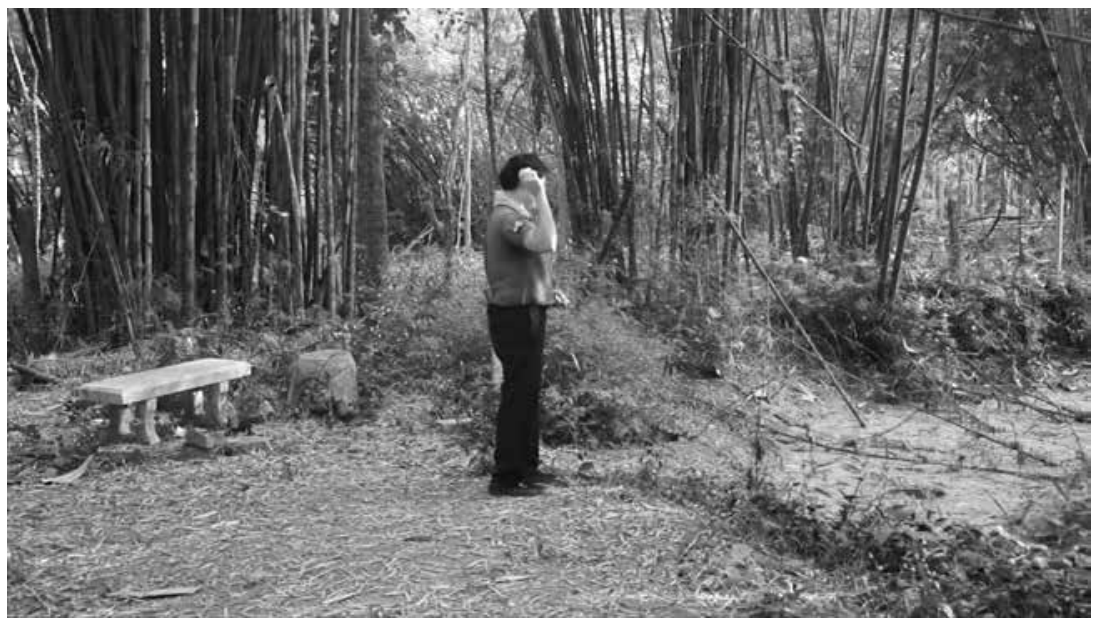

Figure 8.2. Throwing stones scene from The Asylum (dir. Prapat Jiwarangsan, 2015).

The scene moves from establishing shot to a televisual channel-switching sequence that juxtaposes military announcements and comical talk shows. The erasure of protest claims in the hierarchy of media can be read in what Raymond Williams (1989: 133) calls 'televisuality' because this form of information is, we find, a disposition of control: 'We can switch on and off for particular programmes but in some ways the programmes are conceived as a whole and they're often received as a continuity.' This controlled stream, Williams (2003: 91) goes on to argue, is not unlike a city in the sense that appearances converge in the 'planned flow' of the state. Danaya disrupts this continuity by cutting to the ground, the bottom of the vertical hierarchy, where two 'flashlight' shots emanate from the darkness as inversions of the bird's-eye view. The first shot projects a snail emerging from its shell, which escapes the conventions of realism in the more personalized framing of 'latent' power. The film then cuts to a toad that jumps off-screen where protest is converted into disappearance. Hanna Rose Shell (2012) explains that a 'camouflage consciousness' emerges around a will to disappear, especially when cameras assume the taxonomic function of clarifying subjects (from the human to the inhuman) in larger claims to truth. Like camouflage, this kind of film departs from the threat of publicity in the development of its own forms of visibility.

Unlike the 'quadcopter' drones raised above the city, these short films do not portend neutrality. In fact, Night Watch protests the time of the coup through the ominous pulse of a low-pitch audio drone sample. As a cinematic form of negation, the sonic drone is not uncommon in Thai film. 


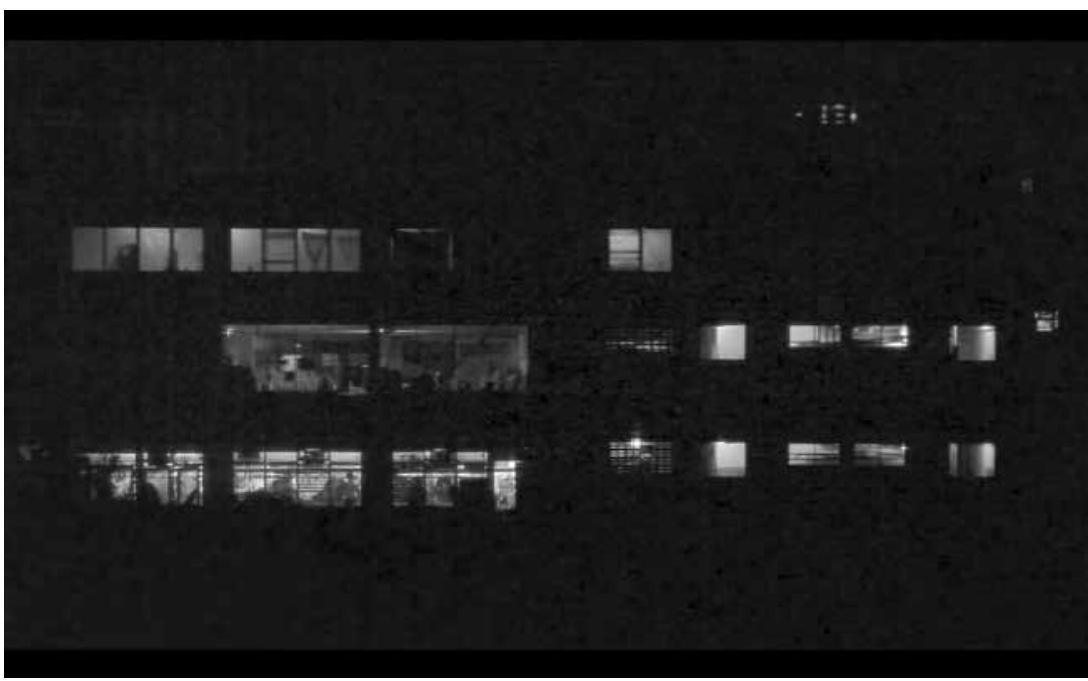

Figure 8.3. The continuity of work during a military coup, from Night Watch (dir. Danaya Chulphuthipong, 2015).

It surfaces in a scene banned from Apichatpong Weerasethakul's Syndromes and a Century (2006) in the aftermath of the 2006 coup, and a scene where memories of the 6 October 1976 protest dematerialize in the digitized global city in Anocha Suwichakornpong's By the Time It Gets Dark (2017). The Thai Ministry of Culture demanded that Nontawat Numbenchapol remove this kind of drone sample to lift a ban on his documentary critique of the Preah Vihear border dispute in Boundary (2013). In Night Watch, these sounds are especially resonant as the colour-coded flickering of red, white, and blue lights flash upon the continuous activities of nearby workers. Sounding the colour scheme of the national flag associates the symbolic trinity of nation, religion, and monarchy with forces that legitimize the coup. Whereas this distribution of sensibility extends into the representational coding of Red Shirts and Yellow Shirts, or 'good' people and 'corrupt' people, the representation of political voice is deformed by noise. Noise reverberates as a critical rejoinder to the impending silence of martial law, Article 44, Article 112, or any other harmonies of the state.

\section{Conclusion}

Political representation is often discussed under the presupposition of a complete image (or count) of sides. The protest drone is an analogy of this 
completeness, but also a recent technological novelty that records protestors with the machine-like precision of objectivity. Drones reinforced the appearance of a body pulled apart as a public plea for military intervention reinventing, even decentralizing, the historic state-led appropriation of radio and television. The drone is also the guise of neutrality in a spectator-led cinema of attractions, but this time linked to the mapping of hostile space and a need for narrative dénouement in an obvious story. The aesthetics of protest, like fiction - though no less real, is far less clear than the representation of protest. The fictionality of Thailand's post-coup cinema disrupts the representation of an ordered debate and interrogates who counts as a political voice during periods when laws are suspended and reformulated according to official perceptions. Consequently, film is an important protest aesthetic for remapping possible positions and sensory dispositions that always remain incomplete. While states prefer to see two sides in search of harmonious consensus, Prapat Jiwarangsan and Danaya Chulphuthipong deform the conventions of cinema and reconsider the relationship between visibility and audibility underlying militarization in Thailand. This contribution is highly significant for imagining the communities of protest to come, since this expanded duration of opposition is reformulating who and what counts as a relevant voice.

\section{References}

Adey, Peter. 2010. AerialLife: Spaces, Mobilities, Affects. Malden, MA:Wiley-Blackwell. Agamben, Giorgio. 2007. Profanations. New York: Zone Books.

Al-Saleh, Asaad. 2015. Voices of the Arab Spring: Personal Stories from the Arab Revolutions. New York: Columbia University Press.

Asavanuchit, Pinit. 2013a. CUagainst Amnesty Bill 5 Nov 2013 [video], YouTube, 12 December. https://www.youtube.com/watch?v=IRKjK_QmxXo. Accessed 31.03.19.

Asavanuchit, Pinit. 2013b. Patha chamai phlob kham [Chamai clash at dusk] [video], YouTube, 1 December. https://www.youtube.com/watch?v=5tInPbosw 3 U. Accessed 31.03.19.

Bordowitz, Gregg. 2003. 'My '8os: My Postmodernism', Artforum 41(7).

Bordowitz, Gregg. 2004. The AIDS Crisis Is Ridiculous and Other Writings, 1986-2003. Cambridge, MA: MIT Press.

Callahan, William. 1998. Imagining Democracy: Reading 'the Events of May' in Thailand. Singapore: Institute of Southeast Asian Studies. 
Chamayou, G. 2015. A Theory of the Drone. New York: The New Press.

Chatakul, Bunika. 2010. Morning After [photograph], Flickr, 12 April. http://www. flickr.com/photos/bunika-snaps/4595427518/. Accessed 31.03.19.

Conley, Tom. 2003. 'The City Vanishes', in After-Images of the City, ed. Joan Ramon Resina and Dieter Ingenschay, 209-224. Ithaca: Cornell University Press.

DeCaroli, Steven. 2007. 'Boundary Stones: Giorgio Agamben and the Field of Sovereignty', in Giorgio Agamben: Sovereignty and Life, ed. Matthew Calarco and Steven DeCaroli, 43-69. Stanford: Stanford University Press.

Dovey, Kim. 2001. 'Memory, Democracy and Urban Space: Bangkok's "Path to Democracy"', Journal of Urban Design 6(3): 265-282.

Fox, William L. 2009. Aereality: On the World from Above. Berkeley: Counterpoint Press.

Hamilton, Annette. 1993. 'Video Crackdown, or the Sacrificial Pirate: Censorship and Cultural Consequences in Thailand', Public Culture 5(3):515-531.

Hariraksapitak, Pracha. 2018. 'Thai PM Now Says Election to Be Held No Later Than Feb 2019', Reuters, 27 February. https://www.reuters.com/article/us-thailandpolitics/thai-pm-now-says-election-to-be-held-no-later-than-feb-2019-idUSKCN1GBoQS. Accessed 31.03.19.

Harvey, David. 2012. Rebel Cities: From the Right to the City to the Urban Revolution. New York: Verso.

Kittler, Friedrich. 1999. Gramophone, Film, Typewriter. Stanford: Stanford University Press.

Klima, Alan. 2002. The Funderal Casino: Meditation, Massacre, and Exchange with the Dead in Thailand. Princeton: Princeton University Press.

Lambert, Léopold. 2013. The Funambulist Pamphlets, Vol. 5: Occupy Wall Street. New York: Punctum Press.

Lee, Alexandra, and Catherine Darin. 2014. 'Martial Law in Thailand's Northeast Creates Common Cause between Pro-democracy, Community Rights Groups', Prachatai, 20 December. http://www.prachatai.com/english/node/4624. Accessed 31.03.19.

Mason, Paul. 2012. Why It's Kicking OffEverywhere: The New Global Revolutions. New York: Verso.

Mirzoeff, Nicholas. 2015. How to See the World. New York: Basic Books.

Mroué, Rabih. 2017. 'The Pixelated Revolution', in Former West: Art and the Contemporary after 1989, ed. Maria Hlavajova and Simon Sheikh, 477-488. Cambridge, MA: MIT Press.

Nietzsche, Friedrich. 2002. Beyond Good and Evil, ed. Rolf-Peter Horstmann and Judith Norman. Cambridge: Cambridge University Press.

Peck, Michael. 2013. 'Now Police Are Shooting Down Drones', Forbes, 26 June. 
Radcliffe, Jack. 2014. 'The "Thaksin Regime" vs. the "Good People", Asian Correspondent, 26 December. https://asiancorrespondent.com/2014/12/the-thaksinregime-vs-good-people/. Accessed 31.03.19.

Rancière, Jacques. 1999. Disagreement. Minneapolis: University of Minnesota Press.

Rancière, Jacques. 2004. The Politics of Aesthetics. London: Continuum.

Rancière, Jacques. 2018. 'Auerbach and the Contradictions of Realism', Critical Inquiry 44: 227-241.

Rose Shell, Hanna. 2012. Hide and Seek: Camouflage, Photography, and the Media of Reconnaissance. Cambridge, MA: MIT Press.

Shapiro, Michael J. 2008. Slow Looking: The Ethics and Politics of Aesthetics: Jill Bennett, Empathic Vision: Affect, Trauma, and Contemporary Art (Stanford, CA: Stanford University Press, 2005); Mark Reinhardt, Holly Edwards, and Erina Duganne, Beautiful Suffering: Photography and the Traffic in Pain (Chicago, IL: University of Chicago Press, 2007); Gillo Pontecorvo, director, The Battle of Algiers (Criterion: Special Three-Disc Edition, 2004)', Millennium:Journal of International Studies 37(1): 181-197.

Sombatpoonsiri, Janjira. 2017. 'The Policing of Anti-government Protests: Thailand's 2013-2014 Demonstrations and a Crisis of Police Legitimacy', Journal of Asian Security and International Affairs 4(1): 95-122.

Sontag, Susan. 1973. On Photography. New York: Picador.

Sopranzetti, Claudio. 2012. Red Journeys: Inside the Thai Red-Shirt Movement. Chiang Mai: Silkworm Books.

Subhatra Bhumiprabhas, Pravit Rojanaphruk, and Pennapa Hongthong. 2006. 'Public Stages Its First Protest', The Nation (Thailand), 23 September. http:// www.nationmultimedia.com/2006/og/23/headlines/headlines_30014455.php. Accessed 31.03.19.

Tejapira, Kasian. 2006. 'Toppling Thaksin', New Left Review 39 (May/June).

Thompson, E.P. 1971. 'The Moral Economy of the English Crowd in the Eighteenth Century', Past \& Present 50: 76-136.

Webb, Simon, and Pairat Temphairojana. 2015. 'Thaksin Tells Thailand's Red Shirt Opposition: "Play Dead ... for Now"', Reuters, 20 September. https://www.reuters. com/article/us-thailand-politics/thaksin-tells-thailands-red-shirt-oppositionplay-dead-for-now-idUSKCNoRKo2F20150920. Accessed 31.03.19.

Williams, Raymond. 1989. Raymond Williams on Television: Selected Writings, ed. Alan O'Connor. New York: Routledge.

Williams, Raymond. 2003. Television: Technology and Cultural Form. New York: Routledge.

Winichakul, Thongchai. 2008. 'Toppling Democracy', Journal of Contemporary Asia 38(1): 11-37. 


\section{About the Author}

Noah Viernes teaches visual culture and social movements as an Associate Professor in the Global Studies Program at Akita International University in Akita, Japan. He is working to complete a documentary film on the Thai-Malay poet Zakariya Amataya and writing about the work of Thai film-maker Apichatpong Weerasethakul. He is from Honolulu, Hawaii. 
